\title{
Aturan Asosiasi untuk Analisis Data Penjualan Produk Menggunakan Algoritma Apriori
}

\author{
Al ichlas*1, Ibnu Rasyid Munthe², Mila Nirmala Sari Hasibuan ${ }^{3}$ \\ ${ }^{1,2,3}$ Universitas Labuhan Batu, Rantau Prapat, Indonesia \\ Email : alichlas24@gmail.com*1, ibnurasyidmunthe@gmail.com², \\ milanirmalasari7@gmail.com ${ }^{3}$
}

\begin{abstract}
Abstrak
PT. Surya Indah City adalah perusahaan yang bergerak di bidang penjualan berbagai macam pakaian dan aksesoris. Dalam upaya meningkatkan penjualan produknya, diperlukan suatu analisis untuk dapat meningkatkan pendapatan perusahaan dengan memanfaatkan data transaksi penjualan yang dimilikinya. Untuk menganalisis hubungan antara produk pakaian dan aksesoris yang lebih dominan dijual dengan produk pakaian dan aksesoris lainnya yang tersedia, digunakan algoritma data mining yaitu algoritma apriori. Dengan bantuan aplikasi tanagra untuk melakukan proses perhitungan, produk dominan yang diminati konsumen dapat ditentukan. Dengan menggunakan dua variabel yang memenuhi support dan minimum confidence maka dapat disimpulkan bahwa produk yang paling banyak terjual adalah dari jenis pakaian yaitu baju dan celana. Disimpulkan bahwa hasil aturan asosiasi akhir diketahui, jika Anda membeli kemeja, Anda akan membeli celana dengan dukungan 50\% dan kepercayaan 75\%. Jika Anda membeli celana, Anda akan membeli pakaian dengan dukungan 50\% dan kepercayaan $85 \%$. Dengan bantuan aplikasi tanagra untuk melakukan proses perhitungan, produk dominan yang diminati konsumen dapat ditentukan. Disimpulkan bahwa hasil aturan asosiasi akhir diketahui, jika Anda membeli kemeja, Anda akan membeli celana dengan dukungan 50\% dan kepercayaan 75\%. Jika Anda membeli celana, Anda akan membeli pakaian dengan dukungan 50\% dan kepercayaan 85\%. Disimpulkan bahwa hasil aturan asosiasi akhir diketahui, jika Anda membeli kemeja, Anda akan membeli celana dengan dukungan 50\% dan kepercayaan 75\%. Jika Anda membeli celana, Anda akan membeli pakaian dengan dukungan 50\% dan kepercayaan 85\%. Disimpulkan bahwa hasil aturan asosiasi akhir diketahui, jika Anda membeli kemeja, Anda akan membeli celana dengan dukungan 50\% dan kepercayaan 75\%. Jika Anda membeli celana, Anda akan membeli pakaian dengan dukungan 50\% dan kepercayaan $85 \%$.
\end{abstract}

Kata kunci-Algoritma Apriori, Penjualan Produk, Analisis, Tanagra

\begin{abstract}
PT. Surya Indah City is a company engaged in the sale of various kinds of clothing and accessories. In an effort to increase product sales, an analysis is needed to increase the company's revenue by utilizing its sales transaction data. To analyze the relationship between clothing products and accessories that are more dominantly sold with clothing products and other available accessories, a data mining algorithm is used, namely the a priori algorithm. With the help of the tanagra application to carry out the calculation process, the dominant product that consumers are interested in can be determined. By using two variables that meet support and minimum confidence, it can be concluded that the most sold products are clothing types, namely shirts and pants. It is concluded that the result of the final association rule is known, if you buy a shirt, you will buy pants with 50\% support and $75 \%$ confidence. If you buy pants, you will buy clothes with 50\% support and 85\% trust. With the help of the tanagra application to carry out the calculation process, the dominant product that consumers are interested in can be determined. It is concluded that the result of the final association rule is known, if you buy a shirt, you will buy pants with 50\% support and 75\% confidence. If you buy pants, you will buy clothes with 50\% support and $85 \%$ trust. It is concluded that the result of the final association rule is known, if you buy a shirt, you will buy pants with 50\% support and $75 \%$ confidence. If you buy pants, you will buy clothes with 50\% support and $85 \%$ trust. It is
\end{abstract}


concluded that the result of the final association rule is known, if you buy a shirt, you will buy pants with 50\% support and 75\% confidence. If you buy pants, you will buy clothes with 50\% support and $85 \%$ trust.

\section{Keywords-Apriori Algorithm, Product Sales, Analysis, Tanagra}

\section{PENDAHULUAN}

Pakaian dan aksesoris merupakan bagian yang sangat penting dari kebutuhan sandang manusia. Berbagai tren dan model terus berkembang dari waktu ke waktu. Saat ini pakaian dan aksesoris tidak hanya menjadi kebutuhan, tetapi sudah menjadi keinginan dalam memenuhi selera pemakainya (Lestari, 2014). Melihat kondisi tersebut, banyak perusahaan yang menjadikan pakaian dan aksesoris sebagai objek penjualan kepada konsumen. Bisnis ini sangat menjanjikan bagi setiap perusahaan untuk mendapatkan keuntungan yang cukup besar jika setiap perusahaan memiliki strategi pemasaran dan penjualan yang baik dalam menghadapi persaingan dengan kompetitor. PT. Surya Indah City adalah perusahaan yang bergerak di bidang penjualan pakaian dan aksesoris. Banyak varian jenis pakaian dan aksesoris dengan berbagai merek yang dijual di perusahaan ini, seperti berbagai model baju, celana, jaket, sandal, topi, kupluk, tas, sepatu dan kaos kaki. Seiring dengan peningkatan penjualan produk, PT. Surya Indah City belum memiliki sistem yang membantu dalam menentukan pola pembelian produk oleh konsumen dengan baik karena belum menggunakan data transaksi penjualan harus dijadikan sebagai tolak ukur dalam mengevaluasi pembelian produk yang harus dilakukan untuk memenuhi stok dari barang di gudang. Akibatnya, perusahaan hanya memprediksi secara konvensional dalam melakukan pemesanan produk dari distributor pada saat persediaan sedikit (Fauziah \& Ratnawati, 2018). Penggunaan data transaksi penjualan sebenarnya dapat digunakan untuk membantu menganalisis pola pembelian yang dilakukan konsumen, bukan hanya digunakan sebagai pendataan (Santoso et al., 2016). Dalam kumpulan data ini, sebenarnya terdapat informasi yang dapat digunakan untuk melihat pola pembelian produk yang terjadi pada setiap transaksi (Putra et al., 2019). Masalah lain yang dihadapi PT. Surya Indah City adalah belum adanya sistem yang menentukan tata letak produk yang dijual. Padahal, sistem tata letak produk yang dipasarkan akan mempengaruhi penjualan produk karena sistem ini dapat memudahkan konsumen dalam membeli produk (Putra et al., 2019).

Berdasarkan permasalahan di atas, penelitian ini merumuskan masalah yaitu: bagaimana penerapan algoritma apriori untuk menentukan pola pembelian pakaian dan aksesoris oleh konsumen dan bagaimana penerapan algoritma apriori untuk mengetahui produk mana yang paling banyak dipilih oleh konsumen. saat membeli produk di PT. Kota Surya Indah.

\section{TINJAUAN LITERATUR}

Menurut (Badrul, 2015) "Data mining adalah suatu teknik yang merupakan gabungan dari metode analisis data secara terus menerus dengan algoritma untuk mengolah data yang besar.". Menurut (Anas, 2016), "Algoritma data mining sebagian besar berasal dari bentuk mengembangkan algoritma di berbagai bidang pembelajaran mesin, statistik, kecerdasan buatan, dan jaringan saraf tiruan. Karena tidak dirancang untuk menangani data dalam ukuran yang sangat besar, sedangkan data mining yang dimaksud berguna untuk menangani data dengan ukuran seperti itu, maka salah satu arah penelitian di bidang data mining adalah mengembangkan algoritma tersebut agar dapat menangani data yang sangat besar. ukuran data". Menurut (Handrianto \& Farhan, 2019) "Data Mining adalah suatu proses yang menggunakan statistik, matematis,

Menurut (Irfiani, 2019), "Data mining adalah suatu metode dengan mengekstraksi informasi dalam jumlah besar, dengan cara ini membantu perusahaan untuk fokus pada informasi penting dalam data warehouse".

Menurut (Gunadi \& Sensuse, 2012), "Data mining adalah proses menganalisis data untuk menemukan pola dari kumpulan data". Data mining mampu menganalisis dan mengolah sekumpulan data menjadi informasi yang dapat menentukan pola-pola yang dapat mendukung suatu keputusan. Ada beberapa algoritma dalam data mining yang dapat kita gunakan untuk 
memprediksi hasil dari pemrosesan sekumpulan data. Salah satunya adalah dengan menggunakan algoritma apriori. Ada beberapa algoritma dalam data mining yang dapat digunakan untuk memprediksi suatu hasil dari pengolahan sekumpulan data, salah satunya dengan menggunakan algoritma apriori.

Menurut (Panjaitan et al., 2020) menyatakan bahwa, "analisis aturan asosiasi dalam data mining adalah teknik data mining untuk menemukan aturan asosiasi antara kombinasi item". Analisis aturan asosiasi dikenal sebagai salah satu teknik data mining yang menjadi dasar dari berbagai teknik data mining lainnya. Tahap analisis aturan asosiasi akan menghasilkan algoritma yang efisien dengan menggunakan pola frekuensi tinggi. Aturan asosiasi ini bertujuan untuk mencari pola yang sering terjadi di antara banyak transaksi, dimana setiap transaksi terdiri dari beberapa item.

Menurut Kusrini dalam (Listriani et al., 2016) menyatakan bahwa "Metodologi dasar analisis asosiasi terdiri dari dua yaitu: analisis pola frekuensi tinggi dan pembentukan aturan asosiatif'.

Tahap ini mencari kombinasi item yang memenuhi persyaratan minimum dari nilai dukungan dalam database. Nilai support suatu item diperoleh dengan rumus 1 berikut ini.

$$
\operatorname{support}(A)=\frac{\text { Total Transksi Mengandung } A}{\text { Total Transaksi }} \times 100 \%
$$

Sedangkan nilai support dari 2 item didapatkan dari rumus 2 berikut ini.

$$
\operatorname{support}(A, B)=\frac{\sum \text { Total Transaksi mengandung } A}{\sum \text { Total Transaksi }} \times 100 \%
$$

Pembentukan aturan asosiasi dilakukan setelah semua pola frekuensi tinggi ditemukan, kemudian aturan asosiasi ditemukan memenuhi persyaratan minimum untuk kepercayaan dengan menghitung kepercayaan aturan asosiatif "jika A maka B". Nilai kepercayaan dari aturan "jika A maka B" diperoleh dari rumus3 berikut:

$$
\operatorname{confidence}(A, B)=\frac{\sum \text { Total Transaksi mengandung A dan } B}{\sum \text { Total Transaksi } A} \times 100 \%
$$

Algoritma apriori, termasuk jenis aturan asosiasi dalam data mining. Selain apriori, yang termasuk dalam kelompok ini adalah metode induksi aturan umum dan algoritma berbasis hash. Aturan yang menyatakan hubungan antar atribut sering disebut analisis afinitas atau analisis keranjang pasar. Analisis asosiasi atau association rule mining merupakan teknik data mining untuk menemukan aturan asosiasi antar kombinasi item (Wulandari, 2017).

Menurut (Rusdiansyah et al., 2020), algoritma Apriori termasuk jenis aturan asosiasi dalam Data Mining. Aturan yang menyatakan hubungan antara beberapa atribut sering disebut analisis afinitas atau analisis keranjang pasar. Analisis asosiasi atau penambangan aturan asosiasi adalah teknik Data Mining untuk menemukan aturan untuk kombinasi item. Menurut (Badrul, 2016), "Algoritma apriori adalah algoritma dasar yang diusulkan oleh Agrawal \& Srikant pada tahun 1994 untuk menentukan frequent itemsets sebagai aturan asosiasi boolean. Sebuah algoritma apriori termasuk jenis aturan asosiasi dalam data mining".

Secara garis besar, kerja dari algoritma apriori adalah:embentukan kandidat itemset, kandidat k-itemset terbentuk dari kombinasi (k-1) -itemset yang diperoleh dari iterasi sebelumnya. Salah satu fitur dari algoritma Apriori adalah pemangkasan kandidat k-itemset yang subsetnya mengandung k-1 item tidak termasuk dalam pola frekuensi tinggi dengan panjang k-1.

a. Perhitungan support untuk setiap kandidat k-itemset. Dukungan dari setiap kandidat kitemset diperoleh dengan memindai database untuk menghitung jumlah transaksi yang berisi semua item dalam kandidat k-itemset. Ini juga merupakan fitur dari algoritma apriori yang membutuhkan perhitungan dengan memindai seluruh database dari k-itemset terpanjang.

b. Atur pola frekuensi tinggi. Pola frekuensi tinggi yang mengandung $\mathrm{k}$ item atau k-itemset ditentukan dari kandidat k-itemset yang supportnya lebih besar dari minimum supportnya. 
Jika tidak ada pola frekuensi tinggi baru yang diperoleh, seluruh proses dihentikan. Jika tidak, maka k ditambah satu dan kembali ke bagian 1 .

Menurut (Badrul, 2016), "Tanagra adalah software data mining gratis dan berguna untuk keperluan akademik dan dapat diambil dari beberapa metode data mining berupa analisis eksplorasi data, pembelajaran statistik, machine learning dan database area". Perangkat lunak Tanagra dikatakan gratis, karena perangkat lunak tersebut bersifat open source dimana setiap peneliti dapat mengakses kode sumber, dan menambahkan algoritmanya sendiri, selama peneliti setuju dan mematuhi lisensi distribusi perangkat lunak.

\section{Tahapan Penelitian}

\section{METODE PENELITIAN}

Metodologi penelitian merupakan tahapan yang sistematis untuk membantu penelitian yang terarah dengan baik. Berikut ini adalah metodologi penelitian yang digunakan dalam penelitian yang dilakukan oleh penulis.

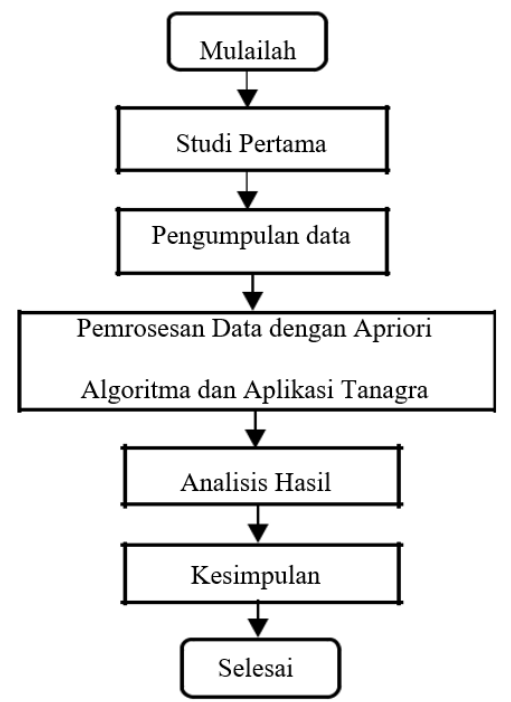

Gambar 1. Tahapan Penelitian

\section{Metode pengumpulan data}

Pengumpulan data penelitian dilakukan dengan cara sebagai berikut:

1. Pengamatan. Perhatikan informasi terkait data transaksi penjualan di PT. Kota Surya Indah. Hasil pengamatan langsung tersebut kemudian dicatat sehingga dapat diketahui penerapan yang dapat dilakukan dengan metode yang akan digunakan.

2. Wawancara. Melakukan wawancara langsung dengan bagian penjualan PT. Surya Indah City, siapa tahu data transaksi penjualan produk yang terjadi di perusahaan selama setahun.

3. Tinjauan Literatur. Mempelajari literatur jurnal ilmiah dan buku referensi untuk mendukung penelitian.

Populasi adalah suatu wilayah generalisasi yang berupa subjek atau objek yang diteliti dan mempunyai sifat-sifat dan ciri-ciri tertentu yang ditentukan oleh peneliti untuk dipelajari, kemudian ditarik kesimpulan". (Sugiyono, 2015). Sedangkan, "Sampel adalah sebagian atau bertindak sebagai wakil dari populasi sehingga hasil penelitian yang berhasil diperoleh dari sampel dapat digeneralisasikan untuk populasi”. (Sugiyono, 2015).

Populasi yang menjadi objek penelitian ini adalah beberapa produk yang dijual di PT. Surya Indah City, dimana jumlah penduduknya adalah 9 produk.

Tabel 1. Populasi

\begin{tabular}{|r|c|c|}
\hline Tidak & Produk untuk & Jumlah \\
\hline & Penjualan & \\
\hline 1 & 9 & 9 \\
\hline & Total & 9 \\
\hline
\end{tabular}


Pada penelitian ini sampel yang akan digunakan untuk menentukan produk mana yang akan dijual secara bersamaan adalah 9 produk. Penelitian ini menggunakan nonprobability sampling, ada beberapa jenis sampel dalam penelitian ini, sampel yang digunakan untuk produk yang dijual secara bersamaan adalah sampel jenuh.

Tabel 2. Sampel Data

\begin{tabular}{|c|c|}
\hline No & Produk Yang Dijuan \\
\hline 1 & Pakaian \\
\hline 2 & Celana \\
\hline 3 & Jaket \\
\hline 4 & Tas \\
\hline 5 & Topi \\
\hline 6 & Skullpas \\
\hline 7 & Sandal \\
\hline 8 & Sepatu \\
\hline 9 & Kaus Kaki \\
\hline
\end{tabular}

\section{HASIL DAN PEMBAHASAN}

Algoritma Apriori biasanya digunakan untuk menemukan aturan asosiasi yang memenuhi persyaratan minimum dukungan dan kepercayaan, yang merupakan kekuatan hubungan antar item dalam aturan asosiasi.

\section{Pembentukan 1 Itemset}

Proses penyelesaian formasi 1 itemset dan $\mathrm{C} 1$ dengan jumlah support $30 \%$ dengan rumus :

$$
\operatorname{support}(A)=\frac{\sum \text { Total Transaksi mengabdung A }}{\sum \text { Total Transaksi }} \times 100 \%
$$

Tabel 3. Itemset

\begin{tabular}{|c|l|l|}
\hline No & Itemset & Support \\
\hline 1 & Pakaian & $66,7 \%$ \\
\hline 2 & Sepatu & $58,3 \%$ \\
\hline 3 & Kaus kaki & $58,3 \%$ \\
\hline 4 & Jaket & $58,3 \%$ \\
\hline 5 & Celana & $58,3 \%$ \\
\hline
\end{tabular}

\section{Pembentukan 2 itemset}

Proses penyelesaian formasi 2 itemset atau C2 dengan jumlah support minimal $30 \%$ dengan rumus :

Support $(\mathrm{A}, \mathrm{B})=\mathrm{P}(\mathrm{A} \cap \mathrm{B})$

$$
\operatorname{support}(A, B)=\frac{\sum \text { Total Transaksi mengabdung } A, B}{\sum \text { Total Transaksi }} \times 100 \%
$$

Tabel 4. Set barang

\begin{tabular}{|c|l|c|}
\hline Tidak & kumpulan barang & Dukung \\
\hline 1 & Pakaian, Sepatu & $33,33 \%$ \\
\hline 2 & Pakaian, Celana & $50 \%$ \\
\hline 3 & Sepatu, Kaus Kaki & $33,33 \%$ \\
\hline 4 & Sepatu, Jaket & $33,33 \%$ \\
\hline 5 & kaus kaki, jaket & $33,33 \%$ \\
\hline
\end{tabular}

\section{Pembentukan Aturan Asosiasi}

Setelah semua pola frekuensi tinggi ditemukan, selanjutnya hitung aturan asosiasi dengan keyakinan minimal $60 \%$ dengan rumus: 


$$
\text { confidence }=P(A \mid B)=\frac{\sum \text { Total Transaksi mengabdung Adan } B}{\sum \text { Total Transaksi } A} \times 100 \%
$$

Tabel 5. Kandidat untuk Aturan Asosiasi

\begin{tabular}{|l|c|c|}
\hline \multicolumn{1}{|c|}{ Aturan } & \multicolumn{2}{c|}{ Confidence } \\
\hline Jika Anda membeli Pakaian, Anda akan membeli Sepatu & $4 / 8$ & $50 \%$ \\
\hline Jika Anda membeli Sepatu, Anda akan membeli Pakaian & $4 / 7$ & $57 \%$ \\
\hline Jika Anda membeli Pakaian, Anda akan membeli Celana & $6 / 8$ & $75 \%$ \\
\hline Jika Anda membeli Celana, Anda akan membeli Pakaian & $6 / 7$ & $85 \%$ \\
\hline Jika Anda membeli Sepatu, Anda akan membeli Socks & $4 / 7$ & $57 \%$ \\
\hline Jika Anda membeli Socks, Anda akan membeli Sepatu & $4 / 7$ & $57 \%$ \\
\hline Jika Anda membeli Sepatu, Anda akan membeli Jaket & $4 / 7$ & $57 \%$ \\
\hline Jika Anda membeli Jaket, Anda akan membeli Sepatu & $4 / 7$ & $57 \%$ \\
\hline Jika Anda membeli Socks, Anda akan membeli Jaket Jacket & $4 / 7$ & $57 \%$ \\
\hline Jika Anda membeli Jaket, Anda akan membeli Kaos Kaki & $4 / 7$ & $57 \%$ \\
\hline
\end{tabular}

\section{Aturan Asosiasi Terakhir}

Aturan asosiasi final diambil berdasarkan aturan asosiasi kandidat yang memenuhi persyaratan yaitu dengan dukungan minimal 30\% dan kepercayaan minimal $60 \%$.

Tabel 6. Asosiasi Terakhir

\begin{tabular}{|c|c|c|}
\hline Aturan & Dukung & Kepercayaan \\
\hline Jika Anda membeli Pakaian, Anda akan membeli Celana & $50 \%$ & $75 \%$ \\
\hline Jika Anda membeli Celana, Anda akan membeli Pakaian & $50 \%$ & $85 \%$ \\
\hline
\end{tabular}

Berdasarkan tabel di atas, produk yang paling banyak terjual adalah membeli baju maka akan membeli celana dengan support $50 \%$ dan confidence $75 \%$ dan jika membeli celana akan membeli baju dengan support 50\% dan confidence $85 \%$. Dengan mengetahui banyaknya produk yang dijual, perusahaan dapat memanfaatkannya untuk tata letak produk penjualan.

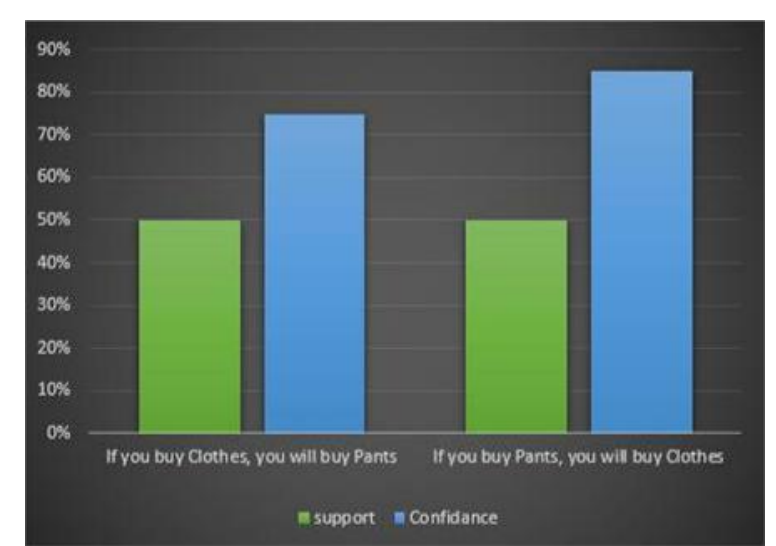

Gambar 2. Diagram Hasil Pembentukan Aturan Asosiasi Akhir

Algoritma untuk menentukan support dapat dilihat dibawah ini yang terdiri dari input, output dan proses. Berikut adalah hasil perhitungan menggunakan Tanagra, 


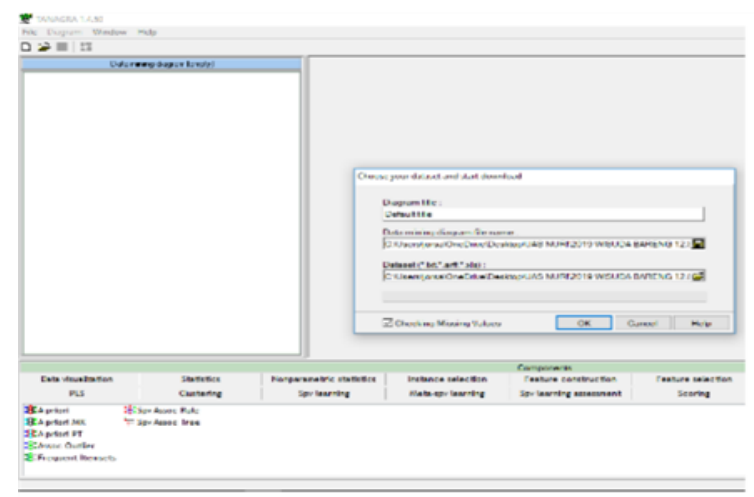

Gambar 3. Proses Masukan

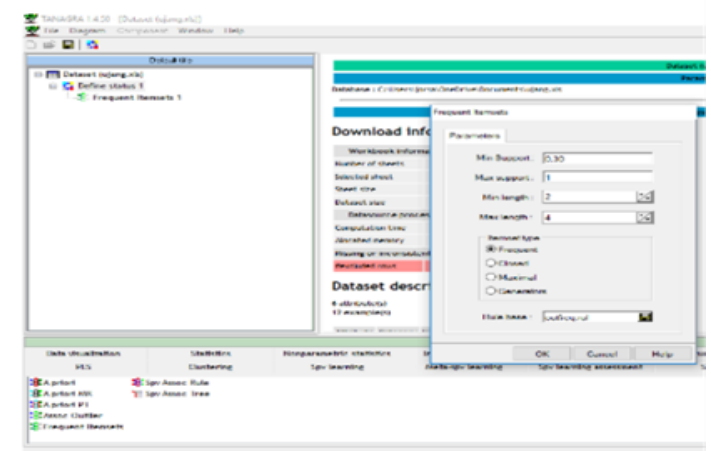

Gambar 4. Isi Parameter Frequent Itemset

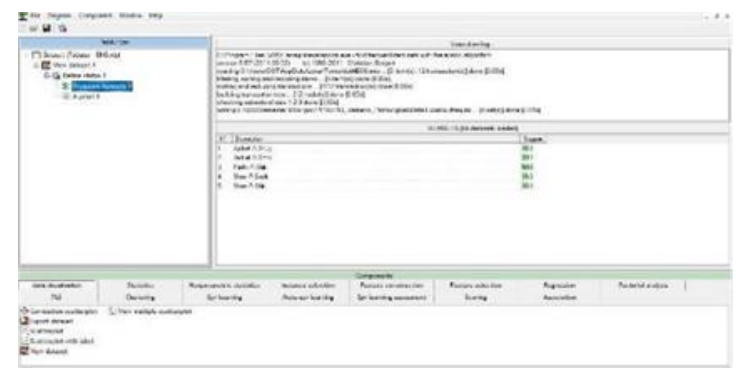

Gambar 5. Lihat Itemset Sering

Algoritma penentuan kepercayaan dapat dilihat di bawah ini yang terdiri dari input, output dan proses. Jika kepercayaan kurang dari 60\% maka aturan asosiasi tidak disertakan. Berikut adalah hasil perhitungan menggunakan Tanagra,

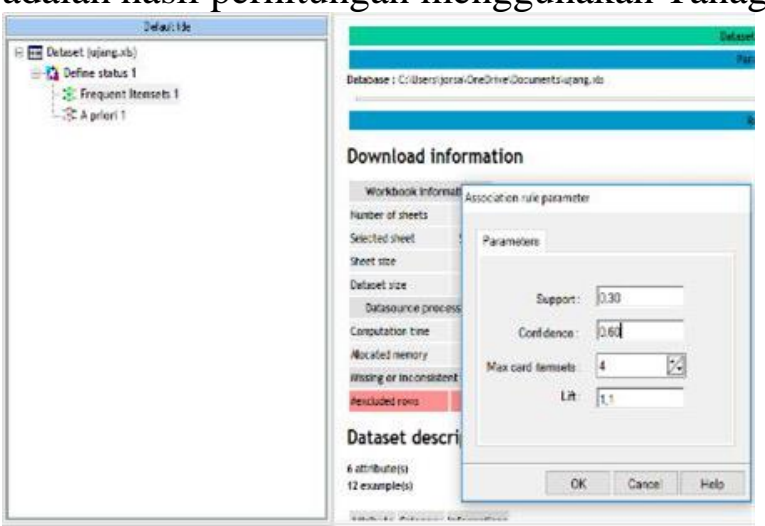

Gambar 6. Parameter Apriori

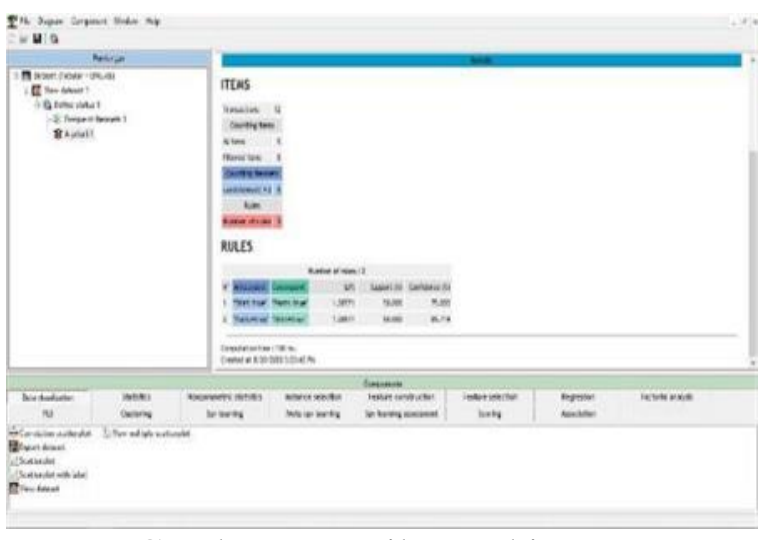

Gambar 7. Hasil Keyakinan

\section{KESIMPULAN}

Dari hasil penelitian yang telah dilakukan untuk melihat penjualan produk tertinggi pada PT. Surya Indah City dengan menggunakan metode Algoritma Apriori dapat disimpulkan bahwa sebagian besar penjualan produk yang dijual di PT. Surya Indah City dapat dicari dengan menggunakan Algoritma Apriori, dengan menggunakan 2 variabel yang memenuhi support dan minimum confidence, produk yang paling banyak terjual adalah baju dan celana. Dari aturan asosiasi terakhir yang diketahui, jika Anda membeli pakaian, Anda membeli celana dengan dukungan 50\% dan kepercayaan 75\%. Jika Anda membeli celana, Anda membeli pakaian dengan dukungan $50 \%$ dan kepercayaan $85 \%$. Algoritma apriori dapat membantu mengembangkan strategi pemasaran untuk memasarkan produk yang dipasarkan dengan mengkaji apa saja keunggulan produk yang paling banyak terjual saat ini.

\section{DAFTAR PUSTAKA}

[1] Anas, A. (2016). Analisa Algoritma Apriori Untuk Mendapatkan Pola Peminjaman Buku Perpustakaan Smpn 3 
[2] Batanghari. Jurnal Ilmiah Media SISFO, 10(2), 628-641. http://ejournal.stikomdb.ac.id/index.php/mediasisfo/article/view/233/220

[3] Badrul, M. (2015). Prediksi Hasil Pemilu Legislatif Dengan Menggunakan Algoritma K-Nearest Neighbor. Jurnal Pilar Nusa Mandiri, XI(2), 152-160. http://ejournal.nusamandiri.ac.id/index.php/pilar/article/view/424/374

[4] Badrul, M. (2016). Algoritma Asosiasi Dengan Algoritma Apriori Untuk Analisa Data Penjualan. Tidak ada, 12(2), 121-129. https://media.neliti.com/media/publications/227549-algoritma-asosiasi-denganalgoritma-apri-f4245cc8.pdf

[5] Fauziah, S., \& Ratnawati. (2018). Penerapan Metode FIFO Pada Sistem Informasi Persediaan Barang. Jurnal Teknik Komputer, 4(1), 98-108.

[6] Gunadi, G., \& Sensuse, DI (2012). Penerapan Metode Data Mining Market Basket Analysis Terhadap Data Penjualan Produk Buku Dengan Menggunakan Algoritma Apriori Dan Frequent Pattern Growth ( Fp-Growth ) : Telematika, 4(1), 118-132.

[7] Handrianto, Y., \& Farhan, M. (2019). C.45 Algoritma Klasifikasi Penyebab Tanah Longsor. SinkrOn, 4(1), 120. https://doi.org/10.33395/sinkron.v4i1.10154

[8] Irfiani, E. (2019). Penerapan Algoritma Apriori untuk Menentukan Asosiasi dalam Peralatan Olahraga Luar Ruangan Toko. SinkrOn, 3(2), 218. https://doi.org/10.33395/sinkron.v3i2.10089 